\title{
Effect Of Investment Decision, Capital Structure, Profitability, And Company Size On Company Values
}

\author{
Reza Suleman ${ }^{1}$ and Sumani ${ }^{2}$ \\ 1,2 Universitas Katolik Indonesia Atma Jaya \\ Email Address: \\ sumani@atmajaya.ac.id
}

\begin{abstract}
This study wanted to examine the effect of investment decisions, capital structure, profitability, and company size on the value of the firm, by using samples from the property, real estate, and construction companies listed on the Indonesia stock exchange for the period 2014-2017. Hypothesis testing using the panel data method by using Eviews version 9. The results of the study showed that the investment decision, capital structure, and profitability did not have a significant effect on firm value. In contrast, the size of the company has a significant adverse effect on the value of the firm. From the results of the F test, investment decision, capital structure, profitability, company size in this study simultaneously influence the value of the firm.
\end{abstract}

Keywords: Investment Decision, Capital Structure, Profitability, Company`s size, value of the firm.

\begin{abstract}
Abstrak: Penelitian ini ingin menguji pengaruh keputusan investasi, struktur modal, profitabilitas, dan ukuran perusahaan pada nilai perusahaan, dengan menggunakan sampel dari perusahaan properti, real estat, dan konstruksi yang terdaftar di bursa efek Indonesia untuk periode 2014- 2017 Pengujian hipotesis menggunakan metode data panel dengan menggunakan Eviews versi 9. Hasil penelitian menunjukkan bahwa keputusan investasi, struktur modal, dan profitabilitas tidak memiliki pengaruh yang signifikan terhadap nilai perusahaan. Sebaliknya, ukuran perusahaan memiliki pengaruh buruk yang signifikan terhadap nilai perusahaan. Dari hasil uji F, keputusan investasi, struktur modal, profitabilitas, ukuran perusahaan dalam penelitian ini secara simultan mempengaruhi nilai perusahaan.
\end{abstract}

Keywords: Keputusasn Investasi, Struktur Modal, Profitabilitas, Ukuran Perusahaan, Nilai Perusahaan.

\section{INTRODUCTION}

Indonesia is currently focusing on pursuing the target of developing national strategic projects in its efforts to create strategic infrastructure in improving the country's economy. The construction of the road sector, the railroad sector, the airport sector, the port sector, and the housing sector is an advantage for companies engaged in the property, real estate, 
and construction sectors. Therefore, the progress of infrastructure development in Indonesia was followed by the increasingly rapid growth of the business sector of the property, real estate, and construction, the competition between companies in the sector became increasingly tight.

In the race to get market demand, companies must have sufficient capital availability in increasing their operational activities. If the company experiences limited capital, the company only has the option to use external funds obtained from creditors in the form of debt or from investors in the form of share capital. For companies that go public, funds obtained from investors are the main focus in meeting the capital needs of the company. With an adequate source of funds from investors, an increase in the company's operational activities can run smoothly, which will have an impact on increasing company profits.

Shareholders or investors will expect a high rate of return on their investment. Therefore, increasing the prosperity of shareholders or investors can be through increasing the value of the company (Iswajuni et al., 2018). (Ross et al., 2016) said that the value of the company is the foundation of the primary purpose of the establishment of the company that is getting maximum profit because increasing the value of the company means increasing the prosperity of the company owner or shareholder of the company. Company value is an indicator for the market in assessing the viability of the whole company (Hestinoviana et al., 2013) and is a reflection of the shareholders' wealth as seen through the market price of the shares (Hermuningsih, 2012)

Various factors can affect a company's value, such as capital structure and investment decision as a proxy in asset growth. Assets are assets owned by a company that is used to carry out operational activities of the company to make a profit. The purpose of increasing assets is to develop the company's operational activities in order to get high profits.

Signaling Theory is a theory that describes an action taken by a company's management that instructs investors about how management sees the company's prospects for the future (Bennet et al., 2019; Brigham et al., 1993). According to signaling theory, investment activity, and high-profit income can provide a positive signal about the growth of the company in the future, so that it can increase stock prices which are used as a reflection of company value (Achmad and Amanah, 2014; Amarudin et al., 2019). According to the signaling theory stated in (Noerirarwan et al., 2012), expenditure on investment by company management in the form of asset growth will be able to provide a positive signal about the company's growth in the future. Thereby increasing market confidence which causes investors to not hesitate in allocating a number of funds to the company, this will have an impact on increasing the company's stock price.

(Prasetya and Yulianto, 2019) and (Sari and Priyadi, 2016) stated that the growth of company assets is an expectation desired by private companies, namely management and external parties such as investors and creditors, this growth is expected to provide a positive aspect for the company in the form of an investment opportunity in the company that is. The prospect of a growing company, for investors, is a profitable thing because the investment invested is expected to provide high returns (Ratnawati, 2007). Asset growth is an investment decision made by company management to develop the company's operational activities in gaining higher profits; high profits lead to the increased prosperity of the company's shareholders which results in increased company value (Ding et al., 2018; Kurniasih and Ruzikna, 2017). This is supported by (Fama and Eugene, 1978) statement 
that the value of the company is solely determined by the investment decisions of the company's management.

According to (Myers, 1984), the pecking order theory states that a company with a high level of profitability is a low debt level because companies with high profitability have abundant internal funding sources. In the pecking order theory, there is no optimal capital structure. Specifically, companies have sequences of preferences (hierarchies) in the use of funds. According to the pecking order theory, there are several sequence scenarios (hierarchies) in choosing funding sources. Companies prefer to use internal sources of funds or internal funding rather than external funding. The internal funds are obtained from retained earnings resulting from the company's operational activities. If external funding is needed, the company will choose from the safest funding sources, namely the lowest risk debt, down to riskier debt, hybrid securities such as convertible bonds, and the last common stock and preferred stock.

Profitability itself is the primary goal of the establishment of a company in order to maintain the sustainability of its business in the future; this is because profitability shows whether the company has good prospects in the future or not (Wijaya and Sedana, 2015). If the management of the company process the company's operations well to obtain profits, the costs incurred for the operation will be low. So that the profits generated will be high, the profits received by the company will affect people's perceptions of seeing the company, which will affect the company's value.

According to (Dewi and Wirajaya, 2013), the size of the company can influence the value of the company due to the high level of total assets of the company. This can result in management more freely in using existing assets in the company, the flexibility of the use of total assets resulted in the ease of the company management in carrying out activities company operations and controlling company activities that will increase company value.

(Prasetya and Yulianto, 2019) and (Prasetyorini, 2013) argues that company size is a scale that can classify the size of a company. (Hermuningsih, 2012) argues that companies that have a large size will be easy to obtain outside funding sources. With easy access to external funding, causing companies to be able to increase their operational activities on an ongoing basis so that it will have an impact on increasing company value.

The gap in the study of the effect of investment decision, capital structure, profitability, and company size on the value of the company is interesting to study, mainly focusing on sectors that are proliferating in Indonesia, namely the property, real estate, and construction sectors. Therefore, researchers are interested in further researching the existence of these research gaps.

\section{THEORETICAL REVIEW}

A stable and rising share price of a company will reflect the high value of the company. Therefore a high value of the company will be followed by a high share price that will increase the prosperity of the shareholders (Hardian and Asyik, 2016). High company value is the expectation of the company's shareholders because, with a high value, it will show the high prosperity of the shareholders. (Sari and Priyadi (2016) stated that high company value would increase market confidence in the company both in the company's current performance and the company's prospects in the future. However, if the company's 
share price decreases, then the value of the company will also decline so that it will have an impact on decreasing the prosperity of shareholders and the increased risk that the company will face (Fama and Eugene, 1978).

Generally, investors use financial ratios to find out the value of a company. These ratios can provide an assessment indicator for outside parties about the company's performance and how its prospects in the future. Detailed ratios to measure the value of the company, one of which is Price to Book Value (PBV). Price to Book Value (PBV) describes how much the market appreciates the book value of a company's stock. Price to Book Value Ratio (PBV) is often used to assess the price of a company's stock. Companies with PBV below the number "1" are usually considered as low-priced shares, while PBV ratios above the value of "1" can be considered as high-priced shares. Price to Book Value can be calculated with (Ross et al., 2016):

$$
P B V=\frac{\text { Market Price Per Share }}{\text { Book Value Per Share }}
$$

The value of a company formed through the stock market value indicator is strongly influenced by investment opportunities. The investment opportunity can give a positive signal about the company's growth in the future, thus increasing the value of the company.

According to the signaling theory in (Noerirarwan et al., 2012) and (Bennet et al., 2019), research, expenditure on investments made by company management in the form of asset growth will be able to give a positive signal about the company's growth in the future. To increase market confidence which causes investors to not hesitate in allocating some funds to the company, this will have an impact on increasing the company's stock price.

Companies with favorable prospects will avoid selling shares to the capital market and look for other sources of funding, such as making loans that exceed the standard capital structure to take advantage of interest in their efforts to increase the company's taxable income. Conversely, companies with unfavorable prospects will tend to sell their shares, so that the risk of bankruptcy is diversified. The announcement of the issuance of shares by a company is generally a signal that management sees a lousy prospect for the company in the future. The company's prospects, as seen from the actions taken by management, will affect the company's capital structure policy, which will later influence the decision of investors to invest their funds into the company. With high profitability, the company's ability to process operational activities and generate profits is also high; this can provide a positive signal to investors so that it can increase the value of the company. Likewise, the large size of the company seen through the company's assets is expected to give a positive signal to investors. This is also supported by (Sawir, 2004), who argues that the strength of a large-sized company is its ability to determine the bargaining power (bargaining power) in a financial contract and allows the size of a large company to be able to produce higher profits due to the high assets owned by the company.

(Zuhro and Suwitho, 2016) stated that assets are assets that are used for the company's operational activities, the growth of assets carried out by the company will cause an increase in the company's operational activities which have an impact on increasing profits earned by the company. (Meidiawati and Mildawati, 2016) stated that company growth is expressed by changes (decreases or increases) in total assets this year compared to changes in total 
assets last year. Companies that have a significant growth in total assets will be more natural to get the attention of investors and creditors because it reflects that the company can generate an increase in profits as seen from the results of the addition of the company's assets (Meidiawati and Mildawati, 2016)

According to (Brigham et al., 1993) and (Jong et al., 2011), the Trade-off Theory provides three statements of debt use that can be used to determine with certainty the optimal capital structure of each company, namely: Companies with high financial risks must have a high rate of return on company assets. Because it is so high in return, so high is the possibility of financial pressures for companies whose operations use tangible assets or real assets. For example, the construction industry can borrow more than companies whose intangible asset values such as service industries; Companies that have high tax rates will be able to borrow more than companies with lower tax rates and/or tax prospects. High tax rates are caused by the high operating profit obtained by companies without any fixed costs, therefore by borrowing from creditors, the company can reduce the tax rate paid due to the payment of fixed costs that arise before taxable income.

According to (Sari and Priyadi, 2016), profitability is the company's ability to earn profits. Investors invest stocks in companies to get returns. The higher the company's ability to earn profits, the greater the return expected by investors, thus making the company's value better (Dewi and Wirajaya, 2013).

Profitability itself is the main objective of the establishment of a company in order to maintain the sustainability of its business in the future; this is because profitability shows whether the company has good prospects in the future or not (Wijaya and Sedana, 2015). If the company's management can process the company's operations well to obtain profits, the costs incurred for these operations will be low. So that the profits generated will be high, the profits received by the company will affect people's perceptions of seeing the company, which will have an impact on the company's value.

According to (Dewi and Wirajaya, 2013), the size of the company can affect the value of the company due to the high level of total assets of the company, which can cause the management to be more flexible in using the assets in the company. The flexibility in using the total assets results in the ease of the company's management in carrying out activities company operations and controlling company activities that will increase company value.

(Prasetyorini, 2013) and (Ambrose et al., 2019) states that company size is a scale that can classify the size of a company. (Hermuningsih, 2012) argues that companies that have a large size will be easy to get external funding sources. The ease of obtaining external funding caused the company to be able to increase its operational activities sustainably so that it will have an impact on increasing company value.

(Aggarwal and Padhan, 2017) researched the Hospitality Industry in India to determine the effect of leverage, size, profitability, asset growth on firm value. The sample from this study consisted of hospitality companies (hotel companies) registered on the Bombay Stock Exchange (BSE) in India during the period 2001-2015. There were 22 companies included in the study criteria sample during the period 2001-2015. The data analysis used in this study is panel data analysis by applying Pooled Least Square, Fixed Effect Model, and Random Effect Model. Leverage in this study was measured using the ratio of total outside liabilities to total net worth (TOL_TNW). Size measured using Ln Total Asset. Profitability measured using Return On Assets (ROA). Investment decision 
measured using Asset Growth Ratio, and value of the firm measured through Enterprise Value (EV), Market Capitalization (Mcap), and Price to book (PBV). The results of this study indicate that leverage has a significant effect on firm value, which has a negative coefficient direction. The size of the company (size) does not have a significant effect on the value of the company, which has a positive coefficient direction. Profitability has a significant influence on firm value, which has a negative coefficient direction. Asset growth has a significant influence on firm value, with a positive coefficient direction.

(Sucuahi and Cambarihan, 2016) conducted research on diversified companies in the Philippines to know the effect of profitability on firm value. The sample from this study is a diversified company registered in the Philippines in 2014 with financial reports in 2014. There were 86 companies included in the sample criteria in this study during 2014. This study used a purposive sampling method. Analysis of the data used in this study is descriptive analysis and to test the hypothesis using multiple regression analysis. Profitability in this study was measured using the Return on Assets (ROA) ratio, and company value was measured using Tobin's $Q$ ratio. The results in this study indicate that profitability has a significant influence on company value, with a positive coefficient direction.

(Meidiawati and Mildawati, 2016) researched manufacturing companies to know the effect of size, profitability asset growth, capital structure, and dividend policy on firm value. In this study, company size was measured using Ln Total Assets. The investment decision was measured using the Growth Ratio. Profitability measured using the Return on Equity (ROE). The capital structure measured using the Debt Equity Ratio (DER). Dividend policy was measured using the Dividend Payout Ratio (DPR), and company value are measured using Price to Book Value (PBV). The sample in this study consisted of 21 manufacturing companies listed on the Indonesia Stock Exchange (IDX) during the period 2012-2014 and selected by purposive sampling. The results of the hypothesis testing study indicate that the size of the company does not affect the value of the company. The company's growth does not affect the value of the company. Profitability affects the value of the company; Capital structure affects the value of the company; The dividend policy does not affect the value of the company.

(Dewi and Wirajaya, 2013) conducted in the manufacturing industry, to determine the effect of capital structure, profitability, and company size on firm value. The company's capital structure is proxy by Debt to Equity Ratio (DER). Profitability is proxy by Return On Equity (ROE). Company size is proxy by Ln total assets, and company value is proxy by Price to Book Value (PBV). The population of this study is the manufacturing industry listed on the Indonesia Stock Exchange in 2009-2011. The method of determining the sample with a purposive sampling method, with some predetermined criteria, the number of samples is 71 manufacturing companies. Research data is secondary data obtained from the Indonesian Capital Market Directory (ICMD) in 2009-2011. The data analysis technique used in this study is the multiple linear regression analysis. The results of this study indicate that capital structure has a negative and significant effect on firm value, profitability has a positive and significant effect on firm value, and firm size does not affect firm value.

(Prasetyorini, 2013) conducted research in Indonesia to determine the effect of company size, leverage, Price Earning Ratio (PER), and profitability on firm value. Company size is proxy by Ln Total Assets. Leverage is proxy by Debt to Equity Ratio 
(DER), and profitability is proxy by Return On Assets (ROA), and company value is proxy by Tobin's Q Ratio. The results showed that company size, leverage, Price Earning Ratio (PER), and profitability simultaneously influenced firm value. Meanwhile, the test results show that company size, Price Earning Ratio, and profitability have a positive influence on company value partially. Meanwhile, the leverage shown does not partially affect the value of the company.

The following is the framework of the study:

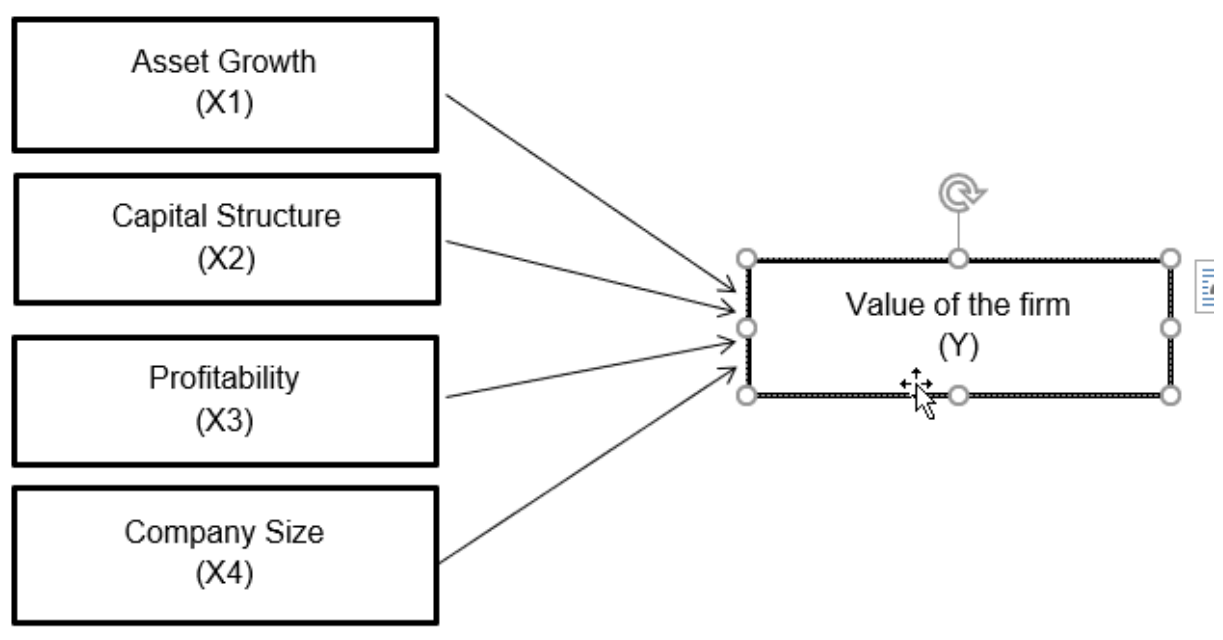

Figure 1. Framework of the study

The Conceptual Hypothesis in this study is as follows:

Effect of investment decision on the value of the firm. Investment decisions that are measured through asset growth are one of the financial management functions that involve fund allocators in various forms of investment decisions to obtain higher profits from future funding costs in order to maximize company value (Achmad and Amanah, 2014). According to (Dhani and Utama, 2017), companies with good asset growth are companies that can manage company resources in generating profits so that they can add company assets, growing company prospects, for investors is a profitable thing because the invested investment is expected to provide a high return (Ratnawati, 2007). This is in line with the research conducted by (Noerirarwan et al., 2012) which states that asset growth has a significant effect on value of the firm, which is also supported by the research of (Aggarwal and Padhan, 2017) which states that asset growth has a significant positive effect on value of the company. Based on the description above, the hypothesis proposed in this study is:

H1: asset growth has a significant effect on the value of the firm.

Effect of capital structure on the value of the firm. The trade-off theory states that companies can use debt fund sources to finance the company's operational activities, but the high use of debt in financing these activities will bring the company to financial distress, a condition that describes a situation where the company cannot fulfill or has difficulties in 
fulfilling its obligations the credit to the creditor is in the form of interest payments if this happens then the value of the company will go down followed by an increase in the company's risk (Brigham et al., 1993). (Sari and Priyadi, 2016) found that capital structure has a significant negative effect on firm value. In line with the study (Safitri and Wahyuati, 2015) and (Aggarwal and Padhan, 2017) found that capital structure (leverage) had a significant negative effect. Based on the description above, the hypothesis proposed in this study is:

H2: Capital structure has a significant effect on the value of the firm.

Effect of profitability on the value of the firm. Company profitability is an indicator of the good and bad of a company in the eyes of investors and creditors. According to (Zuhro and Suwitho, 2016), companies that have high profitability will have high stock prices; this will be used by companies to get additional funds by selling shares whose value has increased. Investors invest in a company to get a return. The higher the company's ability to make a profit, the higher the return expected by investors, thus making the company's value better (Dewi and Wirajaya, 2013). And if the company's management can process the company's operations well to earn a profit, the costs incurred for the operation will be low so that the profits generated will be high, the profits received by the company will affect the perceptions of investors and creditors in seeing the company's performance that will impact the value company. (Hardian and Asyik, 2016) in their study stated that profitability has a significant positive effect on company value, the results of the study are in line with research conducted by (Prasetyorini, 2013) and (Sucuahi and Cambarihan, 2016) which states that profitability has a significant and positive effect on firm value. Based on the description above, the hypothesis proposed in this study is:

\section{H3: Profitability has a significant effect on the value of the firm.}

Effect of company size on the value of the firm. Companies that have a large size means that they have a large market capitalization, this encourages the company to be guaranteed in the eyes of investors and creditors in getting the funding needed by the company. And according to (Sawir, 2004) and (Ambrose et al., 2019), the advantages of large companies are their ability to determine bargaining power in financial contracts and allow large companies to produce higher profits due to the high assets owned by the company. (Hermuningsih, 2012) argues that companies that have a large size will find it easy to obtain outside funding sources, the ease to obtain external funding which will cause the company to be able to increase its operational activities on an ongoing basis so that it will have an impact on increasing company value. (Prasetyorini, 2013) and (Sari and Priyadi, 2016) found that firm size has a significant and positive effect on firm value. Based on the description above, the hypothesis proposed in this study is:

H4: Firm size has a significant effect on the value of the firm. 


\section{METHODS}

In this study the dependent variable used is value of the firm. The valuation of the firm can be measured through a Price to Book Value (PBV) ratio that can be calculated with (Ross et al., 2016):

$$
P B V=\frac{\text { Market Price Per Share }}{\text { Book Value Per Share }}
$$

The independent variables used in this study are investment decision as a proxy in asset growth, capital structure as a proxy in DER, profitability as a proxy in ROE, and company size. Investment Decision: Company asset growth can be measured using the following formula (Aggarwal and Padhan, 2017):

$$
\text { Asset Growth }=\frac{\text { Total Asset }(\boldsymbol{t})-\text { Total Asset }(\boldsymbol{t}-\mathbf{1})}{\text { Total Asset }(\boldsymbol{t}-\mathbf{1})}
$$

The company's capital structure can be measured through Debt to Equity Ratio (DER), which can be calculated with (Ross et al., 2016):

$$
D E R=\frac{\text { Total Liabilities }}{\text { Total Equity }}
$$

Company profitability can be measured through Return On Equity (ROE), which can be calculated with (Ross et al., 2016)

$$
\text { ROE }=\frac{\text { Net Profit After Tax }}{\text { Total Equity }}
$$

Company size can use asset benchmarks, which can be calculated with the natural logarithm value of total assets (Hermuningsih, 2012) through:

$$
\text { Size = Logaritm natural of Total Assets }
$$

The data used in this study is secondary data obtained from the Indonesian Capital Market Directory (ICMD) from 2014 to 2017 for companies listed on the Indonesia Stock Exchange (IDX), which are accessed through (www.idx.co.id). The population of this study uses data on property, real estate, and construction companies listed on the Indonesia Stock Exchange (IDX) from 2014 to 2017 as many as 65 companies. The researcher conducted sampling using the purposive sampling method. The sample was based on the following criteria: Property, real estate and construction companies listed on the Indonesia Stock Exchange (IDX) in 2014 until 2017; Property, real estate and construction companies that have issued audited financial statements for the period 2014 to 2017 respectively which ended on December 31; Property, real estate and construction companies in the industry of property, real estate, and construction, as well as those not included in industrial development board property, real estate, and construction.

The data analysis method used in this study is a descriptive statistical analysis method, panel data regression analysis, and hypothesis testing to conclude the results of the study. 
Processing data and testing hypotheses are done using the program Eviews Version 9.0 with a specified significance value $(\alpha)$ of $5 \%$.

The data in this study is panel data, which is a combination of time series data and cross-section data, so the appropriate regression method to be used in this study is the panel data method. The research steps include: conduct Chow test and Hausman test first to determine a more appropriate regression model between Pooled Least Square, Fixed Effect Model or Random Effect Model; finally the t-Test and F-Test (Greene, 2002).

\section{RESULTS}

The objects used in this study are property, real estate, and construction companies listed on the Indonesia Stock Exchange (IDX) from 2014 until 2017. In searching for sample data from this study, the researchers selected 65 companies in the property, real estate, and construction sectors according to specific criteria during the period 2014 to 2017. The sample selection will be presented in the following table 1 .

Table 1. Sample Selection Table

\begin{tabular}{l|l|c}
\hline No. & \multicolumn{1}{|c}{ Sample Criteria } & \multicolumn{1}{|c}{\begin{tabular}{c}
\multicolumn{1}{c}{ Number of } \\
Samples
\end{tabular}} \\
\hline 1 & $\begin{array}{l}\text { Property, real estate and construction companies listed on the IDX for the period } \\
2014-2017\end{array}$ & 65 \\
\hline 2 & $\begin{array}{l}\text { The company does not issue audited financial statements that expire on } \\
\text { December 31 during the 2014-2017 }\end{array}$ & $(13)$ \\
\hline 3 & $\begin{array}{l}\text { Property, real estate and construction companies that do not enter the main board } \\
\text { in the list of shares on the site www.idx.co.id }\end{array}$ & $((25)$ \\
\hline 4 & $\begin{array}{l}\text { Property, real estate and construction companies that do not have positive asset } \\
\text { growth during 2014 to 2017 }\end{array}$ & $(5)$ \\
\hline & Number of Observation & $\mathbf{2 2}$ \\
\hline & Data Outlier & $\mathbf{( 6 )}$ \\
\hline Source & (pample Amount & $\mathbf{1 6}$ \\
\hline
\end{tabular}

Source: (processed data, 2018) 
Table 2. Descriptive Statistics Analysis

Date: $\quad 07 / 05 / 18$

Time: 08:26

Sample: 20142017

\begin{tabular}{llllll}
\hline \hline & ASSET GROWTH & DER & ROE & \multicolumn{2}{c}{ Ln Total Asset } \\
\hline \hline PBV \\
Mean & 0.137897 & 1.096313 & 0.123264 & 16.24255 & 1.556563 \\
Median & 0.118000 & 1.020000 & 0.121950 & 16.32766 & 1.155000 \\
Maximum & 0.599600 & 2.600000 & 0.243100 & 17.85000 & 4.790000 \\
Minimum & 0.004100 & 0.110000 & 0.008700 & 14.31230 & 0.270000 \\
Std. Dev. & 0.096707 & 0.592307 & 0.057132 & 0.936941 & 1.090828 \\
Observations & 64 & 64 & 64 & 64 & 64 \\
\hline
\end{tabular}

Source: (Output Eviews, 2018)

Based on table 2, the investment decision variable, as measured by the ratio of asset growth, has a minimum value of $0.004100(0.41 \%)$ owned by PT. Modernland Realty Tbk. in 2017 and a maximum value of 0.599600 (59.96\%) owned by PT. Wijaya Karya Tbk. in 2016. The average value of the asset growth variable is 0.137897 (13.79\%), with a standard deviation of 0.096707 .

The capital structure variable measured by Debt to Equity Ratio (DER) has a minimum value of $0.110000(11.00 \%)$ owned by PT. Roda Vivatex Tbk. in 2017 and a maximum value of 2,600 (260.00\%) owned by PT. Wijaya Karya Tbk. in 2015. The average value of the capital structure variable is 1.096250 (109.63\%), with a standard deviation of 0.592264 .

The profitability variable measured by Return to Equity Ratio (ROE) has a minimum value of $0.008700(0.870 \%)$ owned by PT. Duta Anggada Realty Tbk. in 2017 and a maximum value of 0.243100 (24.31\%) owned by PT. Total Bangun Persada Tbk. in 2017. The average value of the profitability variable is $0.123264(12.33 \%)$, with a standard deviation of 0.057132 .

The variable size of the company, as measured by Ln (Total Assets), has a minimum value of 14,331 owned by PT. Roda Vivatex Tbk. in 2014 and a maximum value of 17.85 owned by PT. Lippo Karawaci Tbk. in 2017. The average value of the variable company size is 16.24255 , with a standard deviation of 0.936941 .

The variable value of the firm, as measured by Price to Book Value Ratio (PBV), has a minimum value of 0.27, which is owned by PT. Duta Anggada Realty Tbk. in 2017 and a maximum value of 4.79 owned by PT. Wijaya Karya Tbk. in 2014. The average value of the company value variable is 1.556563 , with a standard deviation of 1.090828 . 
Table 3. Chow Test Results

Redundant Fixed Effects Tests

Equation: Fixed Effect Model

Test cross-section fixed effects

\begin{tabular}{llll}
\hline \hline Effects Test & Statistic & d.f. & Prob. \\
\hline \hline Cross-section F & 9.684514 & $(15,44)$ & 0.0000 \\
Cross-section Chi-square & 93.374263 & 15 & 0.0000 \\
\hline \hline
\end{tabular}

Source: (output Eviews, 2018)

In the Chow Test, data obtained that the probability value of the Chi-square Crosssection is $0.0000<0.05$, so it can be concluded that $\mathrm{H} 0$ is rejected, which means the model that should be used is the Fixed Effect Model. When the selected model is a Fixed Effect Model, it is necessary to do a test again, which is through the Hausman Test to find out whether the study should use a Fixed Effect Model or Random Effect Model.

Table 4. Hausman Test Results

Correlated Random Effects - Hausman Test

Equation: Random Effects Model

Test cross-section random effects

\begin{tabular}{llll}
\hline \hline Test Summary & Chi-Sq. Statistic & Chi-Sq. d.f. & Prob. \\
\hline \hline Cross-section random & 51.568928 & 4 & 0.0000 \\
\hline
\end{tabular}

Source: (output Eviews, 2018)

The probability of a random cross-section listed in table 4 is 0.0000 . Because the level of significance $(\alpha)$ is higher than the probability of a random cross-section $(0.0000>0.05)$, then Ha is accepted. So it can be concluded that the Fixed Effect Model method is better to use in this study than the Random Effect Model. 
Table 5. Results of Multiple Regression Model

Method: Panel Least Squares

Date: 07/05/18 Time: 09:05

Sample: 20142017

Periods included: 4

Cross-sections included: 16

Total panel (balanced) observations: 64

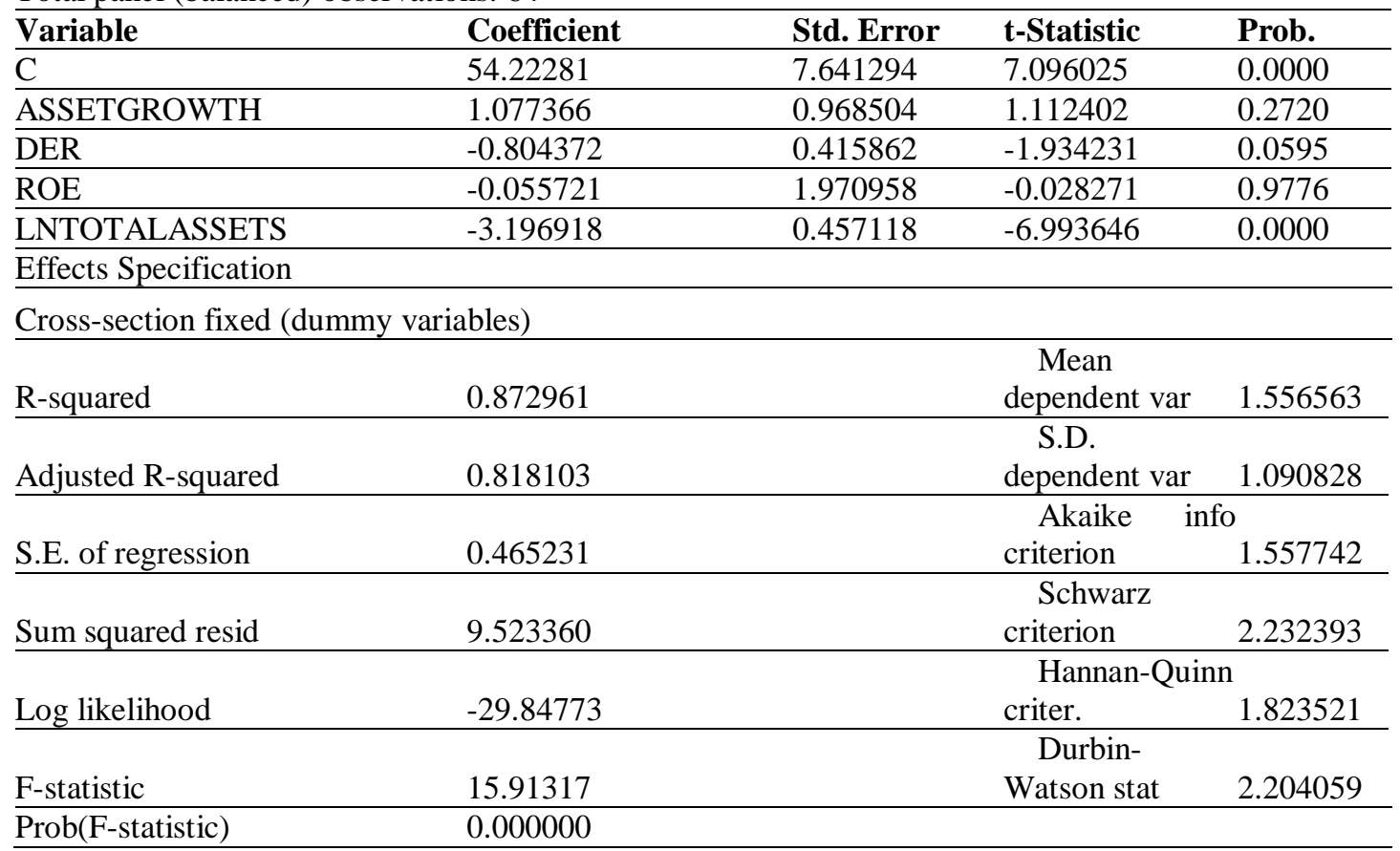

Source: (output Eviews, 2018)

The first hypothesis in this study is the growth of assets. In this study, the investment decision is measured through the Asset Growth ratio. The t-statistical probability value of the asset growth variable is 0.2720 , with a coefficient of 1.077366 . The t-statistical probability value is higher than the significance level $(0.2720>0.0500)$, then $\mathrm{H} 1$ is rejected. This means that partially the investment variable does not have a significant effect on the value of the firm.

The second hypothesis in this study is the capital structure. In this study, capital structure is measured using Debt to Equity Ratio (DER). The probability value t-statistic of capital structure variables is equal to 0.0595 with a coefficient of -0.804372 . The t-statistical probability value is higher than the significance level $(0.0595>0.0500)$, then $\mathrm{H} 2$ is rejected. This means that partially the capital structure variable does not have a significant effect on the value of the firm.

The third hypothesis in this study is profitability. In this study, profitability is measured through the Return On Equity Ratio (ROE). The t-statistical probability value of the asset growth variable is 0.9776 , with a coefficient of -0.055721 . The t-statistical probability value is higher than the significance level (0.9776>0.0500), then $\mathrm{H} 3$ is rejected. This means that partially profitability variables do not have a significant effect on the value of the firm. 
The fourth hypothesis in this study is the size of the company. In this study, the size of the company is measured through Ln Total Assets. The t-statistic probability value of the company size is fixed at 0.0000 with a coefficient of -3.196918 . The t-statistical probability value is lower than the significance level $(0.0000<0.0500)$, then $\mathrm{H} 4$ is accepted. This means that partially the size of the company variable has a significant influence on the value of the firm.

\section{DISCUSSION}

This study shows that investment decisions seen through the growth of company assets show a non-significant effect on firm value. This study found that the growth of assets in the company in carrying out the management function of investing activities did not affect the high and low values of the firm. The results of this study are not in line with the opinion expressed by (Fama and Eugene, 1978). They stated that the value of the firm is solely determined by the investment decisions of the company's management. The results of this study are also not supported by the signaling theory. This states that investment expenditure made by management will provide a positive signal about the firm's growth in the future so that it can increase market confidence, which has an impact on increasing the firm's stock prices, which are used as a reflection of company value. This shows that no matter how large the investment made by the company is seen through the growth of the company's assets, it does not affect the value of the firm. This caused by the high level of investment risk that will be borne in the future will affect investor confidence to invest some funds into the company. The results of this study are consistent with the research conducted by (Achmad and Amanah, 2014) that the effect of investment decision variables measured through growth on firm value is not significant with the direction of the coefficient being negative. And in line with the research conducted by (Ningsih et al., 2014) which states that the growth of company assets does not have a significant effect on firm value. But this research is not consistent with the results of research conducted by (Aggarwal and Padhan, 2017), and (Noerirarwan et al., 2012) which states that asset growth has a significant positive effect on firm value.

The absence of influence between the growth of company assets and company value can be made possible by three things. First, the level of investment risk borne by the company will be significant; companies that increase assets from year to year will need an abundant source of funding. According to the pecking order theory, the funding source of the company has a hierarchy that is, if insufficient, internal funding sources, then the company will switch to funding sources externally, namely lending to creditors. High lending, accompanied by high asset growth, without proper asset management, which is reflected in the absence of an increase in corporate profits, will increase the risk of bankruptcy of the company. The risk arises because the costs of high-interest rates, without an increase in company sales, will allow the interest costs paid by the company will significantly reduce operating income. If this happens, it will affect dividends that will be distributed by the company. The lower dividends distributed by the company, the lower the level of investor confidence in the company over the company's inability to process the number of funds that have been invested. This is supported by research conducted by (Achmad and Amanah, 2014) which states that investment decisions that are reflected in 
asset growth, do not have a significant effect on company value. Due to the high level of investment risk to be borne in the future, which will affect investor confidence to invest some funds into the company. The second reason is if a company uses retained earnings to increase its assets, the higher the costs involved in increasing the assets. The high retained earnings caused by the decision of the company's management will have an impact on the low dividends distributed by the company. Therefore, companies that are growing in increasing their operational activities are better off not sharing profits as dividends. Companies that do not distribute dividends by providing clear information to investors will be able to affect the company's stock price as a reflection of the company's value. This is in line with signaling theory, which states that information is an essential indicator for investors and business practitioners because the information is a record of accurate financial statements that explain the pattern of a company's operational activities and how they affect market perception. The third reason is that the increase in total assets by the company from year to year is only in the form of an increase. However, it cannot be appropriately operationalized. In other words, only the capacity is not operationalized. This means that asset growth does not increase the value of the company, which is reflected in the Price to Book Value ratio.

The results of this study are consistent with research conducted by (Ningsih et al., 2014) which states that the growth of company assets does not have a significant effect on firm value. However, this study is not consistent with the results of research conducted by (Aggarwal and Padhan, 2017), and (Noerirarwan et al., 2012) which states that asset growth has a significant positive effect on firm value.

The second hypothesis $(\mathrm{H} 2)$ which states that the capital did not affect on the value of the firm rejected. This research is not in line with previous research conducted by (Aggarwal and Padhan, 2017); (Kurniasih and Ruzikna, 2017); (Rahmawati et al., 2015); (Sari and Priyadi, 2016) which state that the capital structure has a negative and significant influence on firm value. However, it is consistent with the research conducted by (Noerirarwan et al., 2012) and (Prasetyorini, 2013) which states that capital structure does not have a significant effect on the value of the firm. According to (Brealey and Myers, 2000), the company's capital structure decisions can be said to be a trade-off between interest tax shields and costs of financial distress. Companies may fund debt in order to benefit from a tax shield that causes an increase in profit after corporate tax. However if the use of debt is too high, the company will have difficulty in fulfilling its fixed obligation obligations to creditors in the form of interest payments due to a company's debt high impact the possibility that it will go bankrupt.

The third hypothesis $(\mathrm{H} 3)$ which states that profitability did not affect the value of the firm rejected. Two things can cause the absence of significance from the influence of profitability and value of the firm in this study. First, this study has the criteria that companies must have positive asset growth during the research year, namely 2014-2017. Regular asset growth requires high funding; according to the pecking order theory, the company's funding sources start from retained earnings or internal funding. The company will use funding through internal funding in the form of retained earnings before making external funding, which can increase the company's risk in increasing company assets. Therefore, companies will increase their retained earnings rather than increase dividend distribution to shareholders; the low dividend distribution will affect market perceptions that 
have an impact on the value of the company. Decreasing dividend distribution caused by policies to increase retained earnings causes high or low profitability not to affect the value of the company. The second reason is, profitability in this study has no significant effect, this shows that companies that have high profits will pay off their debt levels first so that the profits generated do not affect the value of the firm. This research is in line with previous research conducted by (Kamila and Yuniati, 2017) which states that profitability has no significant adverse effect on the value of the firm but differs from research conducted by (Aggarwal and Padhan, 2017; (Dewi and Wirajaya, 2013); (Dhani and Utama, 2017); (Prasetyorini, 2013) which states that profitability has a positive and significant effect on firm value.

Fourth hypothesis (H4) which states that the size of the company has a significant effect on the value of the firm received. This is supported by the statement put forward by (Kamila and Yuniati, 2017) That a large company size will tend to increase the portion of debt used in corporate funding policy due to the ease of the company in obtaining funding sources from investors and creditors, however, the increase in debt can negatively affect the value of the company. However, in this study, the size of the company measured through Ln Total Assets shows a significant effect on the value of the firm with a negative coefficient direction. This means that any increase in company assets will reduce the value of the firm. This is due to the large size of the company, which will enable the use of higher debt. The use of high debt will increase the risk to the company. The adverse effects of high risk will have an impact on the decline in the value of the firm. For example, in 2014, WIKA had a capital structure condition measured through DER of 2.20x and had a company size measured by Ln Total Assets of 16.58, with a company value of 4.79x. However, in 2015 WIKA increased the capital structure condition to 2.60x and had the size of the company as measured by Ln Total Assets increased by 16.79, with the value of the company decreasing by $2.99 x$. Investors tend to withdraw funds from a company if the company has a high risk. Therefore, the research is proven. (Zuhro and Suwitho, 2016) suggest that large companies have easy access to high funding sources so that the flexibility of large companies is also higher. This causes the company to tend to increase the proportion of the company's debt is expanding the company; this encourages the level of risk for debt that is increasingly high. If the company cannot process the results of the company's expansion well, then the bankruptcy rate of the company will increase, this will result in a decrease in the value of the firm.

\section{CONCLUSION}

Based on the results of the research that has been carried out, some conclusions are summarized as follows: (1) Investment Decision, as measured by Asset Growth Ratio, does not have a significant effect on the value of the firm. (2) The capital structure, as measured by Debt Equity Ratio (DER), does not have a significant on the value of the firm. (3) Profitability, as measured by Return On Equity (ROE), does not have a significant effect on the value of the firm. (4) Firm size measured by Ln Total Assets has a significant effect on the value of the firm.

For investors or potential investors, in making investments, the proxy of Ln Total Assets that reflects the size of the company need to be considered further because it will 
affect the company's current and future values. The size of the company needs to be taken into consideration by investors; investors should not only be tempted by the company's high assets but rather the need to pay attention to where funding sources in increasing the company's assets.

\section{REFERENCES}

Achmad, S. L., dan Amanah, L. (2014). Pengaruh Keputusan Pendanaan, Kebijakan Dividen, dan Kinerja Keuangan Terhadap Nilai Perusahaan. Jurnal Ilmu \& Riset Akuntansi, 3(9).

Aggarwal, D., and Padhan, P. C. (2017). Impact of capital structure on firm value: Evidence from Indian Hospitality Industry. Theoretical Economics Letters, 7(4), 982-1000.

Amarudin, Adam, M., Hamdan, U., and Hanafi, A. (2019). Effect Of Growth Opportunity, Corporate Tax, And Profitability Toward Value Of Firm Through Capital Structure (Listed Manufacturing Companies Of Indonesia). Finance: Theory and Practice, 23(5), 18-29.

Ambrose, B. W., Fuerst, F., Mansley, N., and Wang, Z. (2019). Size effects and economies of scale in European real estate companies. Global Finance Journal, 42. https://doi.org/https://doi.org/10.1016/j.gfj.2019.04.004.

Bennet, B., Stulz, R., and Wang, Z. (2019). Does the stock market make firms more productive? Journal of Financial Economics. https://doi.org/https://doi.org/10.1016/j.jfineco.2019.09.006

Brealey, R. A., and Myers, S. C. (2000). Principles Of Corporate Finance. Mc-Graw-Hill.

Brigham, Eugene, F., \& Gapenski, L. C. (1993). Intermediate Financial Management. Harcourt Brace College.

Dewi, A. S. M., dan Wirajaya, A. (2013). Pengaruh Struktur Modal, Profitabilitas, dan Ukuran Perusahaan Pada Nilai Perusahaan. E-Jurnal Akuntansi Universitas Udayana, 4(2), 358-372. https://doi.org/. https://doi.org/ISSN : 2302-8556

Dhani, I. P., dan Utama, A. G. S. (2017). Pengaruh Pertumbuhan Perusahaan, Struktur Modal, dan Profitabilitas Terhadap Nilai Perusahaan. Jurnal Riset Akuntansi Dan Bisnis Airlangga, 2(1), 135-148.

Ding, S., Kim, M., and Zhang, X. (2018). Do firms care about investment opportunities? Evidence from China. Journal of Corporate Finance, 52, 214-237.

Fama, and Eugene, F. (1978). The Effect of a Firm Investment and Financing Decisison on the Welfare of its Security Holders. American Economic Review, 68, 271-282.

Greene, W. H. (2002). Econometric Analysis (5th ed.). Prentice Hall International, Inc.

Hardian, A. P., dan Asyik, N. F. (2016). Kinerja Keuangan dan Ukuran Perusahaan Terhadap Nilai Perusahaan, CSR Sebagai Variabel Moderasi. Jurnal Ilmu \& Riset Akuntansi, 5(9), 1-16.

Hermuningsih, S. (2012). Pengaruh Profitabilitas, dan Size, Terhadap Nilai Perusahaan Dengan Struktur Modal Sebagai Variabel Intervening. Jurnal Siasat Bisnis, 16(2), 232-242.

Hestinoviana, V., Handayani, S. R., and Suhadak. (2013). The Influence of Profitability, Solvability, Asset Growth and Sales Growth Toward Firm Value Empirical Study on Mining Companies Which Listed on Indonesia Stock Exchange. Brawijaya Journal of 
Financial, 4(1).

Iswajuni, I., Manasikana, A., and Soetedjo, S. (2018). The effect of enterprise risk management (ERM) on firm value in manufacturing companies listed on Indonesian Stock Exchange year 2010-2013. Asian Journal of Accounting Research, 3(2), 224 235. https://doi.org/https://doi.org/10.1108/AJAR-06-2018-0006.

Jong, A. de, Verbeek, M., and Verwijmeren, P. (2011). Firms' debt-equity decisions when the static tradeoff theory and the pecking order theory disagree. Journal of Banking \& Finance, 35(5), 1303-1314.

Kamila, D. R., dan Yuniati, T. (2017). Pengaruh Ukuran Perusahaan, Leverage, Profitabilitas, dan Struktur Modal Terhadap Nilai Perusahaan. Jurnal Ilmu Dan Riset Manajemen, 6(3).

Kurniasih, B., dan Ruzikna. (2017). Pengaruh Struktur Modal dan Keputusan Investasi terhadap Nilai Perusahaan Pada Industri Makanan dan Minuman Yang Terdaftar Di BEI. Jom Fisip, 4(2).

Meidiawati, K., dan Mildawati, T. (2016). Pengaruh Size, Growth, Profitabilitas, Struktur Modal , Kebijakan Dividen Terhadap Nilai Perusahaan. Jurnal Ilmu Dan Riset Akuntansi, 5(2), 1-16.

Myers, S. C. (1984). Capital Structure Puzzle. Journal of Finance, 39(3), 575-592.

Ningsih, E. S., Efni, Y., dan Halim, E. H. (2014). Pengaruh Kepemilikan Institusional, Pertumbuhan Aset Dan Profitabilitas Terhadap Nilai Perusahaan Dengan Kebijakan Dividen Sebagai Intervening Variable. JOM Fekon, 1(2).

Noerirarwan, Ronni, M., dan Muid, A. (2012). Pengaruh Faktor Internal dan Eksternal Perusahaan Terhadap Nilai Perusahaan. Journal of Accounting, 1(2), 1-12.

Prasetya, R. A., and Yulianto, A. (2019). Determinants of Investment Decisions with Growth Opportunities as Moderating Variable. Accounting Analysis Journal, 8(1), 17 23.

Prasetyorini, B. F. (2013). Pengaruh Ukuran Perusahaan, Leverage, Price Earning Ratio dan Profitabilitas terhadap Nilai Perusahaan. Jurnal Ilmu Manajemen, 1(1), 183-196.

Rahmawati, A. D., Topowijono, dan Sulasmiyati, S. (2015). Pengaruh Ukuran Perusahaan, Profitabilitas, Struktur Modal, dan Keputusan Investasi Terhadap Nilai Perusahaan ( Studi pada Perusahaan Sektor Properti , Real Estate , dan Building Construction yang Terdaftar di Bursa Efek Indonesia ( BEI ) Periode 2010-201. Jurnal Administrasi Bisnis, 23(2), 1-17.

Ratnawati, T. (2007). Pengaruh Langsung dan Tidak Langsung Faktor Ekstern, Kesempatan Investasi dan Pertumbuhan Assets Terhadap Keputusan Pendanaan Perusahaan yang Terdaftar Pada Bursa Efek Jakarta (Studi pada Industri Manufaktur Masa Sebelum Krisis dan Saat Krisis). Jurnal Akuntansi Dan Keuangan, 9(2), 65-75.

Ross, S. A., Westerfield, R. W., Jordan, B. D., Lim, J., and Tan, R. (2016). Fundamentals of Corporate Finance (2nd ed.). New York: McGraw-Hill Education.

Safitri, N., dan Wahyuati, A. (2015). Pengaruh Struktur Modal dan Keputusan Investasi terhadap Profitabilitas dan Nilai Perusahaan. Jurnal Ilmu Dan Riset Manajemen, 4(2).

Sari, R. A. I., dan Priyadi, M. P. (2016). Pengaruh Leverage , Profitabilitas , Size , dan Growth Opportunity Terhadap Nilai Perusahaan. Jurnal Ilmu Dan Riset Manajemen, 5(10), 2-17.

Sawir, A. (2004). Analisis Kinerja Keuangan dan Perencanaan Keuangan Perusahaan. PT. 
Gramedia Pustaka Utama.

Sucuahi, W., and Cambarihan, J. M. (2016). Influence of Profitability to the Firm Value of Diversified Companies in the Philippines. Accounting and Finance Research, 5(2).

Wijaya, B. I., dan Sedana, I. B. P. (2015). Pengaruh Profitabilitas Terhadap Nilai Perusahaan (Kebijakan Dividen dan Kesempatan Investasi Sebagai Variabel mediasi. E-Jurnal Manajemen Unud, 12(4477-4500).

Zuhro, F., dan Suwitho. (2016). Pengaruh Ukuran Perusahaan, Pertumbuhan Aset, dan Profitabilitas terhadap Struktur Modal. Jurnal Ilmu Dan Riset Manajemen, 5(5), 1-16. 